\title{
Multiple Cropping in the Hillsides of Jamaica ${ }^{1}$
}

\author{
Abdul H. Wahab, Percy Aitken-Soux, \\ Irving Johnson, César Paniagua, Bo-Myeong Woo, \\ Howard Murray, Joseph Dehaney and \\ Miguel A. Lugo-López ${ }^{2}$ \\ ABSTRACT
}

\begin{abstract}
Results of a project aimed at increasing production of hillside lands through application of multiple cropping systems and intensive cultivation of lands are presented. Data obtained over a 5-year cropping period indicate that useful biomass production could be tripled through adequate cropping systems. Yam yields were not adversely affected by intercropping with legumes, corn, tubers and root crops. Yam as a monocrop produced 40 to $48 \mathrm{t} /$ ha in the first cropping year; then yields declined gradually to approximately $20 \mathrm{t} /$ ha by the 5 th. year. When intercropped, maximum yam yields were $55 \mathrm{t} / \mathrm{ha}$ in the first year and followed the same declining trend as the yam monocrop in succeeding cropping seasons. Irish potato, as an intercrop, produced 9 to $15 \mathrm{t} / \mathrm{ha}$ of good quality tubers in 4 out of 5 years. Red beans, cowpeas, ginger, peanuts and radish were good intercrops in some years. Onions, corn, pumpkin, cabbage, carrot, cassava, and sweetpotatoes performed poorly as intercrops.
\end{abstract}

\section{INTRODUCTION}

Jamaica is located in lat. $18^{\circ} \mathrm{N}$ and long. $77^{\circ} \mathrm{W}$. The island is 4,411 square miles $\left(11,400 \mathrm{~km}^{2}\right), 80 \%$ of which is hilly to mountainous. Over $50 \%$ of the island is characterized by slopes of $20^{\circ}$ and greater and, as a consequence, only $30 \%$ of the total area is suitable for mechanized agriculture. The flat lands are dedicated mainly to the cultivation of export crops such as sugarcane and banana, whereas the hilly lands supply most of the domestic foodstuffs and substantial quantities of animal protein.

The Allsides Project, in southern Trelawny, encompasses 251 ha and consists of 233 farm families totalling 1,398 individuals (3). A detailed topographic survey of the project indicates that over $55 \%$ of the area is characterized by slopes $15^{\circ}$ and greater (4).

Yam (Dioscorea spp.), is an important staple in Jamaica $(1,2,3)$. It is grown by almost every hillside farmer in the project area who generally cultivates the crop on individual mounds with little or no regard to soil erosion control measures. The overall objective of the project herein reported was to develop appropriate technologies for intensive hillside farming terraced land using cropping systems conducive to changing the

${ }^{1}$ Manuscript submitted to Editorial Board June 15, 1984.

${ }^{2}$ The first five authors, IICA/Jamaica Specialists; Agronomist and Soil Conservation Officer, respectively, Ministry of Agriculture/Jamaica; and Professor and Soil Scientist (ret.), now Consultant, College of Agricultural Sciences, University of Puerto Rico, Mayagüez Campus. 
traditional pattern of hilly land farming (4). Specifically, it was expected to develop systems for bench terraces which could result in increased levels of production (6). Thus, increased farm income, enhanced nutritional profiles of farm families, and increased opportunities for rural employment could be expected.

\section{MATERIALS AND METHODS}

Following construction of terraces in early 1977 and prior to crop establishment, limestone in the form of marl and poultry manure each at the rate of $3 \mathrm{t} / \mathrm{ha}$ were applied. The experimental site was located in the Allsides area of the Parish of Trelawny, at an altitude of approximately 800 meters above sea level.

The soil is an Ultisol locally classified as Wirefence clay loam. It is very acid $(\mathrm{pH} 4.9)$ and contains high levels of exchangeable Al. It is relatively infertile as evidenced by medium to low levels of $\mathrm{N}, \mathrm{P}$ and $\mathrm{K}$. Annual precipitation over a 4-year period (1977-1981) averaged $1878 \mathrm{~mm}$ and was characterized by a bimodal distribution pattern with wettest periods occurring in May and October. Maximum temperatures range from $24^{\circ} \mathrm{C}$ to $29^{\circ} \mathrm{C}$, while minimum temperatures range from $15^{\circ} \mathrm{C}$ to $23^{\circ}$ C. Hottest months are July, August and September and coolest months are November, December and January.

A total of 20 systems of production were tested during the crop years 1977-78 and 1978-79. They are described in tables 1, 2, 3, 4 and 5. Beginning in October 1978 and again in March 1979, 1980 and 1981, respectively, work continued on the further refinement of eight of the more promising cropping systems.

In the 1978-79 crop year, corn was again tested and new crops such as the dwarf determinate variety of pigeonpea (UWI-17), bodie bean (Vigna spp.), peanut and lettuce were included in the tests.

To ascertain yield response of yams and other crop combinations when established during the September-October rainy season, four production systems were tested on semi-commercial sized plots. The cropping systems consisted of: 1) yam as a sole crop; 2) yam grown together with peanut followed in sequence by Irish potato and radish; 3) yam grown together with peanuts followed by Irish potato; 4) yam grown together with African red beans and followed by peanut.

Following a detailed review of the results obtained from April 1977 to February 1979, eight crop systems were established during the period March 1979 to February 1980 on whole terraces, thereby simulating farmers' terraced plots in size. These terraces varied in size from 0.02 to 0.07 ha.

Irrespective of the cropping pattern, rates of fertilizer application for the first two crop years remained constant as follows: $\mathrm{N}, 200 \mathrm{~kg} / \mathrm{ha}$ as 
urea or ammonium sulphate; $\mathrm{P}_{2} \mathrm{O}_{5}, 300 \mathrm{~kg} / \mathrm{ha}$ as triple superphosphate; and $\mathrm{K}_{2} \mathrm{O}, 150 \mathrm{~kg} / \mathrm{ha}$ as muriate of potash.

In 1980, the fertilizer dosage was adjusted upwards to conform to a commercially availale blend (12:24:12) which the farmers use. The fertilizer was applied as follows: for the yam monocrop, $730 \mathrm{~kg} / \mathrm{ha}$ was banded circularly 6 weeks after the "heads" were planted. This was followed by a similar application 8 weeks later (14 weeks after planting). The $\mathrm{N}$ sidedressing ( $133 \mathrm{~kg} / \mathrm{ha}$ urea or $60 \mathrm{~kg} / \mathrm{ha} \mathrm{N}$ ) was applied 28 weeks from planting. For the yam intercrop, $300 \mathrm{~kg} / \mathrm{ha}$ was applied 6 and 14 weeks from planting, followed by the application of $130 \mathrm{~kg} / \mathrm{ha}(12: 24: 12)$ and $44 \mathrm{~kg} / \mathrm{ha}$ urea $(20 \mathrm{~kg} / \mathrm{ha} \mathrm{N})$ at 28 weeks from planting. For the intercrops such as red beans, cowpeas, peanuts and Irish potatoes, $365 \mathrm{~kg} / \mathrm{ha}$ of 12:24:12 was placed in furrows $5-8 \mathrm{~cm}$ below the seed. This was followed at flowering by the application of $44 \mathrm{~kg} / \mathrm{ha}$ urea $(20 \mathrm{~kg} / \mathrm{ha} \mathrm{N})$. For the ginger intercrop, 12:24:12 at the rate of $365 \mathrm{~kg} / \mathrm{ha}$ was banded at 6 and 18 weeks from planting. This was followed at 24 weeks from planting with an application of $133 \mathrm{~kg} / \mathrm{ha}$ urea $(60 \mathrm{~kg} / \mathrm{ha} \mathrm{Nn})$ banded 5 to $8 \mathrm{~cm}$ away from the ginger rows at a depth of 5 to $8 \mathrm{~cm}$.

Irrespective of whether yellow yam (Dioscorea cayenensis) was grown as a monocrop or in association with other crops, plant density was kept constant at 10,000 plants/ha. Yam "heads" were planted on the ridges of continuous mounds spaced $1.4 \mathrm{~m}$ apart. One yam "head" was planted at every 0.66 to $0.67 \mathrm{~m}$ interval along the mound. This requires approximately $8 \mathrm{t} / \mathrm{ha}$ of planting material. Wooden stakes 3 to $4 \mathrm{~m}$ in length were placed between adjacent mounds with each stake equidistant from four yam plants.

Irish potato (Solanum tuberosum) cvs. Red Pontiac, Spunta, Draga and Sebago, when intercropped with yam at the beginning of the crop cycle, was planted in rows $0.75 \mathrm{~m}$ apart and 0.25 to $0.30 \mathrm{~m}$ within the row for a population of 53,000 plants/ha.

Peanut (Arachis hypogaea) of the Valencia type, when grown as an intercrop with yam at the beginning of the crop cycle was planted in rows $0.4 \mathrm{~m}$ apart with an intrarow spacing of $0.1 \mathrm{~m}$. This results in a crop density of 250,000 plants/ha. Intercropped during the latter half of the crop cycle, seeds are planted in rows peripheral to the yam at a population of 125,000 plants/ha. The quantity of unshelled material required was 78 and $40 \mathrm{~kg} / \mathrm{ha}$, respectively.

The spatial arrangement employed for red beans (Phaseolus spp.) and cowpeas (Vigna spp.) at the beginning of the crop cycle followed rows 0.4 $\mathrm{m}$ apart with seeds planted $0.15 \mathrm{~m}$ within the row for a population of approximately 166,000 plants/ha. Cropped with yam during the latter half of the crop year, seeds were planted in $0.4 \mathrm{~m}$ row peripheral to two consecutive yam mounds. Crop density was thus reduced to 83,000 plants/ 
ha. Red bean cultivars used were Miss Kelly and Tom Red, whereas the cowpea used was the African Red type. At the beginning of the crop cycle, seed requirements of red beans and cowpeas were $84 \mathrm{~kg}$ and $15 \mathrm{~kg} /$ ha, respectively. Planted during the latter half of the crop cycle seed requirement was reduced by one-half.

Radish, when grown following the harvest of Irish potato, was seeded directly in rows $0.40 \mathrm{~m}$ apart and $0.15 \mathrm{~m}$ within the row. This required $0.3 \mathrm{~kg} / \mathrm{ha}$ of seed material.

Ginger (yellow), when grown with yam for most of the crop year was planted in rows $0.4 \mathrm{~m}$ apart and 0.35 to $0.30 \mathrm{~m}$ within the row; this required approximately $4.4 \mathrm{t} / \mathrm{ha}$ of seed material. Red beans of the Tom Red variety grown together with yam and ginger during the first quarter of the crop cycle were seeded in rows spaced $0.40 \mathrm{~m}$ apart alternated by ginger rows. Seeds were placed at $0.20 \mathrm{~m}$ within the row. The quantity of seed required was $44.0 \mathrm{~kg} / \mathrm{ha}$.

Corn (Zea mays) of the Pioneer X-306 Hybrid, grown together with yam during the first quarter of the crop year, was seeded in rows spaced $0.70 \mathrm{~m}$ apart and $0.25 \mathrm{~m}$ within the row. This gave a population of approximately 50,000 plants/ha and required $18 \mathrm{~kg} / \mathrm{ha}$ of seed material.

Cabbage (Brassica oleraceae) of the KK Hybrid, grown with yam during the latter half of the crop cycle, was sown at the rate of 33,000 plants/ ha. The quantity of seed required was $0.1 \mathrm{~kg} / \mathrm{ha}$. Field observations included crop adaptability; total and marketable crop yields, under both monocropping and intercropping situations; and crop performance as affected by various planting dates.

\section{RESULTS AND DISCUSSION}

Table 1 gives data on yields of each crop component tested during the 1977-1978 crop year. Yam yields were excellent when compared with those obtained by farmers in the project area (10-15 t/ha of marketable roots). Yields ranged from a low of $26.57 \mathrm{t} / \mathrm{ha}$ in the cropping system where sweetpotato and red beans were grown in association with yam to a high of $40 \mathrm{t} / \mathrm{ha}$ in the system where sweetpotato was established in the latter half of the crop cycle after the failure to obtain an acceptable crop stand of ginger.

Except for cropping system number 8 (yams grown in association with sweetpotato followed by red beans) there was an appreciable increase in total yam output by every other treatment compared with the check treatment (yam monocrop, system No. 1). Further, Irish potato cv. Red Pontiac planted together with yam and harvested 85 days later, produced a yield of more than $9 \mathrm{t} / \mathrm{ha}$ of good quality tubers.

It was significant that other component crops such as onion, corn, pumpkin, cabbage, carrot, cassava, and sweet potato performed poorly. 
TABLE 1.-Marketable yields of monocrop yam (Dioscorea cayenensis) and yam and other crops grown in a polyculture system at Allsides, Trelawny, 1977-78 crop year

\begin{tabular}{|c|c|c|c|c|}
\hline $\begin{array}{l}\text { Cropping } \\
\text { systems }\end{array}$ & Crops & $\begin{array}{l}\text { Marketable } \\
\text { yield }\end{array}$ & "Head" yield & $\begin{array}{l}\text { Change in total } \\
\text { yam yield over } \\
\text { monocrop }\end{array}$ \\
\hline & & \multicolumn{2}{|c|}{$t / h a$} & $\%$ \\
\hline 1 & Yam monocrop & 31.502 & 16.917 & 0 \\
\hline \multirow[t]{3}{*}{2} & Yam & 36.794 & 16.692 & 10.46 \\
\hline & Red beans & 0.552 & & \\
\hline & Onion & 0.053 & & \\
\hline \multirow[t]{3}{*}{3} & Yam & 38.752 & 17.274 & 15.71 \\
\hline & Sweet corn & $7500^{1}$ & & \\
\hline & Red beans & 0.124 & & \\
\hline \multirow[t]{3}{*}{4} & Yam & 35.441 & 16.713 & 7.71 \\
\hline & Grain corn & 0.761 & & \\
\hline & Irish potatoes & 0.489 & & \\
\hline \multirow[t]{4}{*}{5} & Yam & 34.480 & 17.289 & 6.92 \\
\hline & Irish potatoes & 9.286 & & \\
\hline & Radish & 1.587 & & \\
\hline & African red beans & 0.296 & & \\
\hline \multirow[t]{3}{*}{6} & Yam & 38.734 & 17.840 & 16.84 \\
\hline & Pumpkin & 0.000 & & \\
\hline & Sweet corn & $3133^{\mathrm{I}}$ & & \\
\hline \multirow[t]{4}{*}{7} & Yam & 33.006 & 17.010 & 3.30 \\
\hline & Cabbage & 0.695 & & \\
\hline & Carrot & 0.108 & & \\
\hline & Red beans & 0.093 & & \\
\hline \multirow[t]{3}{*}{8} & Yam & 26.565 & 13.668 & -16.91 \\
\hline & Sweetpotatoes & 2.129 & & \\
\hline & Red beans & 0.105 & & \\
\hline \multirow[t]{3}{*}{9} & Yam & 36.794 & 15.861 & 8.75 \\
\hline & Cassava & 0.000 & & \\
\hline & Red beans & 0.539 & & \\
\hline \multirow[t]{3}{*}{10} & Yam & 39.899 & 17.032 & 17.58 \\
\hline & Ginger & 0.000 & & \\
\hline & Sweetpotatoes & 1.616 & & \\
\hline
\end{tabular}

${ }^{1}$ Ears of corn.

Table 2 shows yield data for each cropping system for 1978-79 crops. Except for System 6, in which yams were grown with peanut and sweetpotato, an increase in marketable yam yield over the yam monoculture was recorded for each of the other systems tested.

Further systems in which yam was intercropped with Irish potato, ginger and peanut produced marketable yields of $7.15,3.06$ and $2.13 \mathrm{t} /$ ha, respectively, of these intercrops during the first half of the cropping cycle.

Again, as observed in the 1977-78 crop, corn, onion, sweetpotato and carrot performed poorly as intercrops. Pigeonpeas yielded poorly; lettuce 
TABLE 2.-Marketable yields of monocrop yam (Dioscorea cayenensis) and yam and other crops grown in a polycultyure system at Allsides, Trelawny during the 1978-79 crop year

\begin{tabular}{|c|c|c|c|c|}
\hline $\begin{array}{l}\text { Cropping } \\
\text { systems }\end{array}$ & Crops & $\begin{array}{l}\text { Marketable } \\
\text { yield }\end{array}$ & "Head" yield & $\begin{array}{l}\text { Change in total } \\
\text { yam yield over } \\
\text { monocrop }\end{array}$ \\
\hline & & \multicolumn{2}{|c|}{ t/ha } & $\%$ \\
\hline 1 & Yam monocrop & 10.90 & 10.40 & 0 \\
\hline \multirow[t]{3}{*}{2} & Yam & 14.08 & 10.74 & 16.5 \\
\hline & Corn & 0.304 & & \\
\hline & Pigeonpea & 0.125 & & \\
\hline \multirow[t]{3}{*}{3} & Yam & 15.82 & 11.16 & 26.7 \\
\hline & Red beans (Ms. Kelly cv.) & 0.455 & & \\
\hline & Ginger & 3.058 & & \\
\hline \multirow[t]{3}{*}{4} & Yam & 12.60 & 9.78 & 5.1 \\
\hline & Bodie bean (Vigna sp.) & $2.470^{1}$ & & \\
\hline & Onion & 0.131 & & \\
\hline \multirow[t]{4}{*}{5} & Yam & 13.37 & 8.83 & 4.2 \\
\hline & Irish potato & 6.15 & & \\
\hline & Radish & 0.312 & & \\
\hline & Cowpea (African red cv.) & 0.298 & & \\
\hline \multirow[t]{3}{*}{6} & Yam & 10.32 & 9.18 & -8.5 \\
\hline & Peanut & 2.13 & & \\
\hline & Sweetpotato & 0.00 & & \\
\hline \multirow[t]{3}{*}{7} & Yam & 13.97 & 11.18 & 18.1 \\
\hline & Irish potato & 8.15 & & \\
\hline & Peanut & 0.274 & & \\
\hline \multirow[t]{4}{*}{8} & Yam & 14.93 & 10.85 & 21.0 \\
\hline & Cowpea (African red cv.) & 0.373 & & \\
\hline & Irish potato & 0.718 & & \\
\hline & Lettuce & 0.00 & & \\
\hline \multirow[t]{3}{*}{9} & Yam & 14.16 & 12.08 & 23.19 \\
\hline & Red beans (Tom red cv.) & 0.316 & & \\
\hline & Peanut & 0.163 & & \\
\hline \multirow[t]{3}{*}{10} & Yam & 15.80 & 11.54 & 28.36 \\
\hline & Carrot & 0.099 & & \\
\hline & Bodie bean & $0.127^{1}$ & & \\
\hline
\end{tabular}

${ }^{1}$ Fresh pod yield.

seeds failed to germinate. Overall, the legume mixes resulted in a fair level of performance.

Table 3 shows the yield of yams and each component crop area. Total yam yield was highest ( $27 \mathrm{t} / \mathrm{ha}$ ) when this crop was grown as a monoculture, and production declined by an average of $23 \%$ as other crops were intercropped with yam.

Notwithstanding periods of sustained drought conditions which could have led to the overall lowering of yam yields, peanut performed well on the terraces planted together with yam in the first half of the cropping 
year. Yields of whole sound kernels, expressed at a moisture content of $10 \%$, averaged $1.46 \mathrm{t} / \mathrm{ha}$ and $0.78 \mathrm{t} / \mathrm{ha}$ during the first and latter halves respectively of the yam crop cycle.

Yields of the intercrops were very good for the most part. For instance, the Irish potato intercrop produced $13.25 \mathrm{t} / \mathrm{ha}$ of marketable tubers, whereas the peanut and cowpea intercrops produced 2.51 and $1.506 /$ ha, respectively of excellent quality grains. The radish crop performed well, and when viewed in the context of its short maturity period ( $4-5$ weeks), appears promising.

Table 4 shows yields of marketable yam as a monocrop in 1979-80. It should be noted that these yields were greatly affected by the high incidence of "burning" ${ }^{3}$ Earlier reaping and better monitoring that year

TABLE 3.-Marketable yields of monocrop yam (Dioscorea cayenensis) and yam and other crops in a polyculture system at Site 11, Allsides, during the Oct. 1978-Nov. 1979 cropping period

\begin{tabular}{|c|c|c|c|c|}
\hline $\begin{array}{l}\text { Cropping } \\
\text { systems }\end{array}$ & Crops & $\begin{array}{l}\text { Marketable } \\
\text { yield }\end{array}$ & "Head" yield & $\begin{array}{l}\text { Change in total } \\
\text { yam yield over } \\
\text { monocrop }\end{array}$ \\
\hline & & \multicolumn{2}{|c|}{$t / h a$} & $\%$ \\
\hline 1 & Yam monocrop & 14.79 & 12.11 & 0 \\
\hline \multirow[t]{4}{*}{2} & Yam & 9.79 & 9.42 & -28.6 \\
\hline & Peanut & 1.46 & & \\
\hline & Irish potato & 2.47 & & \\
\hline & Radish & 1.59 & & \\
\hline \multirow[t]{3}{*}{3} & Yam & 10.56 & 8.02 & -30.9 \\
\hline & Peanut & 1.43 & & \\
\hline & Irish potato & 2.13 & & \\
\hline \multirow[t]{3}{*}{4} & Yam & 15.16 & 9.12 & -9.7 \\
\hline & Red bean (African red cv.) & 0.337 & & \\
\hline & Peanut & 0.78 & & \\
\hline
\end{tabular}

reduced that problem somewhat, but there were instances where the

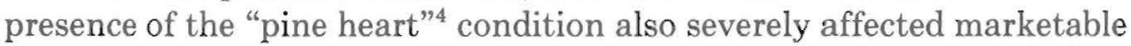
yield. Yam quality was good and physically the yams were "solid". The three intercrops provided excellent canopy cover which reduced the necessity for weeding the yams after the May rains.

The red bean yield was not encouraging $(0.49 \mathrm{t} / \mathrm{ha})$. This has been the pattern, on the demonstration site, whenever red beans are planted in the spring. Crop stand and vigor on the continuous mounds were significantly lower than when the same seeds were sown at the same time

${ }^{3}$ Dry rot of yam tubers caused by the nematode Pratylenchus coffeae.

${ }^{4}$ A condition characterized by a grainy texture which renders the tuber rubbery upon cooking and thus unmarketable. 
within the project area but not on mounds. The reasons for this variation are not apparent.

Performance of the ginger crop were disappointingly poor compared to the excellent yields obtained the previous year. Climatic conditions were favorable, for the most part, and the planting material was of good quality. The plant stand following termination was unacceptable and this

TABLE 4.-Marketable yields of monocrop yam (Dioscorea cayenensis) and yam and other crops groun in a polyculture system at Allsides, Trelawny during the period March 1979-Feb. 1980

\begin{tabular}{|c|c|c|c|c|}
\hline $\begin{array}{l}\text { Cropping } \\
\text { systems }\end{array}$ & Crop & $\begin{array}{l}\text { Marketable } \\
\text { yield }\end{array}$ & $\begin{array}{l}\text { New Yam } \\
\text { "Head" } \\
\text { yield }\end{array}$ & $\begin{array}{l}\text { Change in total } \\
\text { yam yield over } \\
\text { monocrop }\end{array}$ \\
\hline & & \multicolumn{2}{|c|}{ t/ha } & $\%$ \\
\hline 1 & Yam monocrop & 13.03 & 9.85 & 0 \\
\hline \multirow[t]{4}{*}{2} & Yam & 9.80 & 9.88 & -14.0 \\
\hline & Irish potato & 13.25 & & \\
\hline & Radish & 1.27 & & \\
\hline & Peanut & 0.77 & & \\
\hline \multirow[t]{3}{*}{3} & Yam & 7.53 & 8.71 & -29.0 \\
\hline & Peanut & 2.51 & & \\
\hline & Red pea (Miss Kelly cv.) & 0.40 & & \\
\hline \multirow[t]{3}{*}{4} & Yam & 8.22 & 9.06 & -24.5 \\
\hline & Cowpea (African red cv.) & 1.50 & & \\
\hline & Peanut & 0.45 & & \\
\hline \multirow[t]{3}{*}{5} & Yam & 9.50 & 8.02 & -23.4 \\
\hline & Red beans (Tom red cv.) & 0.34 & & \\
\hline & Ginger & 13.87 & & \\
\hline \multirow[t]{2}{*}{6} & Yam & 7.33 & 5.12 & -45.6 \\
\hline & Sweetpotato & 1.31 & & \\
\hline \multirow[t]{3}{*}{7} & Yam & 13.08 & 9.92 & 0.52 \\
\hline & Grain corn & 0.28 & & \\
\hline & Cabbage & 0.00 & & \\
\hline \multirow[t]{3}{*}{8} & Yam & 7.95 & 8.25 & 29.2 \\
\hline & Red beans (IICA/Duva cv.) & 0.73 & & \\
\hline & Cowpea (African red) & 0.43 & & \\
\hline
\end{tabular}

clearly affected the yield. It is apparent that rhizomes undergo a period of dormancy which could exceed six months at times. The yield was merely a recovery of the planting material.

Yield data for the 1980-81 period (table 5) indicate that when yam was intercropped, yields were generally better than those obtained in the previous crop year (1979-1980). For example, the cropping system yam + Irish potato + radish + peanut yielded $11 \mathrm{t} / \mathrm{ha}$ vs. $9.8 \mathrm{t} / \mathrm{ha}$ for yam in the same system the previous year. This improvement would probably 
have been more marked had it not been for the high incidence of "pine heart" and to a lesser extent "hollowing" which rendered a high portion of the yield unmarketable. In the case of yam + peanut + red pea; yam + cowpea + peanut and yam + red pea + ginger, the yam yields increased from 7.5 to $10 \mathrm{t} / \mathrm{ha} ; 8.2$ to $12.9 \mathrm{t} / \mathrm{ha}$ and 9.5 to $12.1 \mathrm{t} / \mathrm{ha}$, respectively.

TABLE 5.-Marketable yields of monocrop yam (Dioscorea cayenensis) and yam and other crops in a polyculture system at Allsides, Trelawny, during the 1980-81 crop year

\begin{tabular}{|c|c|c|c|c|}
\hline $\begin{array}{l}\text { Cropping } \\
\text { systems }\end{array}$ & Crops & $\begin{array}{l}\text { Marketable } \\
\text { yield }\end{array}$ & "Head" yield" & $\begin{array}{l}\text { Change in total } \\
\text { yam yield over } \\
\text { monocrop }\end{array}$ \\
\hline & & \multicolumn{2}{|c|}{$t / h \alpha$} & $\%$ \\
\hline 1 & Yam monocrop & 12.86 & 5.34 & - \\
\hline \multirow[t]{3}{*}{2} & Yam & 12.94 & 5.04 & -1.2 \\
\hline & Cowpea & 0.96 & & \\
\hline & Peanut & 0.29 & & \\
\hline \multirow[t]{4}{*}{3} & Yam & 11.00 & 7.26 & 0.33 \\
\hline & Irish potato & 12.00 & & \\
\hline & Radish & 0.13 & & \\
\hline & Peanut & 0.29 & & \\
\hline \multirow[t]{2}{*}{4} & Yam & 12.09 & 8.32 & 12.14 \\
\hline & Ginger & 1.27 & & \\
\hline \multirow[t]{3}{*}{5} & Yam & 10.00 & 3.62 & 25.16 \\
\hline & Peanut & 1.40 & & \\
\hline & Red beans & 0.03 & & \\
\hline \multirow[t]{4}{*}{6} & Yam & 13.24 & 8.90 & 6.68 \\
\hline & Red beans & 0.49 & & \\
\hline & Radish & 0.68 & & \\
\hline & Cowpea & 0.03 & & \\
\hline
\end{tabular}

1 "Head" weights were recorded at time of planting, 4 to 6 weeks following harvest. Consequently yields were lower due to moisture loss and dry weight loss from tissue respiration.

\section{RESUMEN}

Se informan los resultados de un proyecto para desarrollar sistems de producción en las laderas de las montañas de Jamaica. El objetivo era aumentar la producción mediante sistemas de cosechas múltiples intercaladas cultivadas intensivamente que, a la vez, fueran eficaces en la conservación del suelo. Los datos obtenidos durante un periodo de cinco años indican que la producción de biomasa utilizable puede triplicarse mediante el uso de sistemas apropiados de cultivo. En el período experimental, los rendimientos de ñame no se afectaron adversamente cuando se intercalaron las siembras de ñame con leguminosas, maíz y cosechas farináceas. El ñame, como monocultivo, produjo de 40 a $48 \mathrm{Tm} /$ ha durante

\footnotetext{
${ }^{5}$ A condition characterized by the presence of a cavity within the tuber, such cavity resulted from a sudden burst of growth after a sustained period of drought.
} 
el primer año; luego los rendimientos se redujeron gradualmente hasta aproximadamente $20 \mathrm{Tm} / \mathrm{ha}$ en el quinto año. Cuando se intercalaron otras cosechas, se obtuvieron rendimientos máximos de ñame de hasta $55 \mathrm{Tm} / \mathrm{ha}$ en el primer año y éstos siguieron la misma tendencia que los de ñame en monocultivo en años subsiguientes. Los rendimientos de papa, como cosecha intercalada, fluctuaron entre 9 y $15 \mathrm{Tm} /$ ha de tubérculos de buena calidad en cuatro de los cinco años del estudio. Las habichuelas, los frijoles, el mani, el jenjibre y los rábanos se comportaron bien en algunos años. Otras cosechas como cebolla, maíz, calabaza, zanahoria, yuca y batata no fueron compatibles como cosechas intercaladas con el ñame.

\section{LITERATURE CITED}

1. Aitken-Soux, P., A. H. Wahab, and I. E. Johnson, 1980. The Allsides post peasant, IICA/Jamaica Publication IV-14.

2. Carey-Lawrence, B., 1980. Farming family and nutrition in Allsides, Trelawny-a report of six case studies, M.Sc. Thesis U.W.I., Kingston, Jamaica.

3. Wahab, A. H., 1978. Farming systems for hillsides, Hillside Farming in Jamaica. IICA/ Jamaica Publication III-2 p. 149-61.

4. IICA/Jamaica, 1976. Hillside farming study and implementation project (Allsides Pilot Development Project). Private circulation, Government of Jamaica and IICA.

5. IICA/Jamaica. 1980. Agro-socio-economic Survey-Pilot Hillside Agricultural Project (PHILAGRIP)

6. McDonald, R. C. E. and A. H. Wahab, 1978. Fertility assessment of newly terraced hillside soils using the microplot technique - The Allsides Case Study, IICA/Jamaica Publication I-14.

7. Caribbean Food and Nutrition Institute, 1974. Food Composition Tables - For use in the English speaking Caribbean, C.F.N.I. Kingston 7, Jamaica. 